\title{
Spatial Variability of Soil Cadmium Content and Delineation of its Risky Zones in a Field in Bahr El-Baqar Region \\ Shaddad, S. M. ${ }^{1}$; E. A. El-Naka ${ }^{1}$ and M. Y. Hendawi ${ }^{2}$ \\ ${ }^{1}$ Soil science department, faculty of agriculture, Zagazig University \\ ${ }^{2}$ Plant protectionde partment, faculty of agriculture, Zagazig University
}

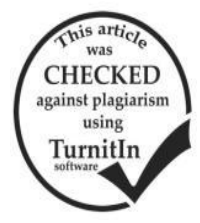

\section{ABSTRACT}

Soil pollution with heavy metals is a great concern as this considerably affects plant both quantity and quality and consequently animal and human health. Detection of the spatial distribution of heavy metals provides good source of information for appropriate soil remediation procedures. Geostatistics and its different interpolators are of great importance for revealing the spatial distribution of any soil variable. The aim of this work is to delineate the spatial distribution of cadmium content insoil irrigated with polluted drainage water of Bahr El-Baqardrain. A total of 100 soil samples were collected over a field of 4.6 ha located in Bahr El-Baqar area, Sharkia Governorate, Egypt. Ordinary kriging was applied as an interpolator for cadmium content interpolation. Prediction assessment was performed using cross-validation calculating two different statistics; mean error (ME) and mean squared standardized error (MSSE). Results showed that the model is unbiased and accurate since ME and MSSE values were of -0.004 and 1.17 respectively. Three management zones were obtained based on cadmium content named as zone 1 , zone 2 and zone 3and their range values were $0.500-$ $1.140,1.141-1.676$ and $1.677-2.125$, respectively. The delineated zones indicate that the field has different multiplicative degrees of cadmium pollution regarding agricultural land use. It is recommendedthat such polluted soils must be appropriately remediatedbefore agricultural land use. It is also recommended that the irrigation water source that comes from Bahr El-Baqardrain should be substituted with a good unpolluted irrigation source.

Keywords: Spatial variability, management zones, soil heavy metals, kriging

\section{INTRODUCTION}

Soil contamination in the region of Bahr El-Baqar is a result of the utilization of polluted water that comes from Bahr El-Baqar drain in irrigating that soils. Bahr ElBaqar drain water contains different pollutants of heavy metals such as lead, cadmium, nickel, and mercury (Park and Shin, 2006). Bahr El-Baqar drain collects untreated wastewater from two main drains, the first is Belbeis drain and the second is Qalubiya drain (Taha et al., 2004). The main sources of the gathered wastewater are industrial activities, agricultural and municipal wastewater. The concentration of heavy metals in Bahr El-Baqar water drain followed the order: $\mathrm{Fe}>\mathrm{Zn}>\mathrm{Mn}>\mathrm{Cu}>\mathrm{Pb}>\mathrm{Ni}>\mathrm{Cd}$ (El-Eweddy, 2000). Heavy metals content measured in the soils of Bahr EL-Baqar region decreases as follows: Cd > $\mathrm{Cu}>\mathrm{Zn}>\mathrm{Cr}>\mathrm{Ni}>\mathrm{Pb}$ (Omran and Abd El Razek, 2012). Cadmium is considered as one of the most hazardous pollutants as this negatively affects agricultural soil even at low concentration (Onweremadu and Duruigbo, 2007; Yobouet et al., 2010). Kidney disease is the main effect of cadmium on human health. However pulmonary, cardiovascular, and musculoskeletal systems were reported among the adverse effects of cadmium(Robertsa, 2014). The spatial distribution of soil heavy metals is essential to assess their risk in order to establish a decision-making framework for land use and management.

The detection of spatial distribution of soil parameters is essential for identifying the management zones (Shaddad et al., 2016) and it allows to give a decision whether to exploit soil in agriculture or in residential use. This can be achieved using spatial model systemof geostatistics which enable the users to guesstimate soil variables at un-sampled locations. The estimation is then non-destructive, time saving and provides fine-scale information as compared with the traditional methods of laboratory soil analysis. The delineated management zones can be used in different aspects in soil sciences such as soil remediation, soil reclamation, and soil fertility management etc (Shaddad and Hendawi, 2018). One of the most unbiased geostatistical estimators is ordinary kriging, it is called "best linear unbiased estimator" (BLUE) (Castrignano, 2011). Therefore, ordinary kriging was the most common used to predict and map soil parameters at un-visited locations (Lopez-Granados et al., 2015; Meul and Van Meirvenne, 2003; Sumfleth and Duttmann, 2008).

The aim of this work is to delineate and identify the critical polluted spotsof the investigated areaby classifying it into different zones based on the risk of cadmium content and to give a resolution approach for soil management and irrigation water sources.

\section{MATERIALS AND METHODS}

\section{Site description and sampling}

This study was conducted on an approximate area of4.6 ha field located in Bahr El-Baqar region, Sharkia Governorate, Egypt (30 ${ }^{\circ} 51^{\prime} 53.31^{\prime \prime}$ N, 32 02 ' 50.45' E). The study area has been cultivated for about ten consecutive years and has been directly irrigated with contaminated water from Bahr El-Baqar drain without any pretreatment. A total of 100 soil samples (Fig.1) based on a quite regular grid $25 \mathrm{~m} \times 25 \mathrm{~m}$ at $0.20 \mathrm{~m}$ depth were collected and transported to the soil laboratory for analysis.

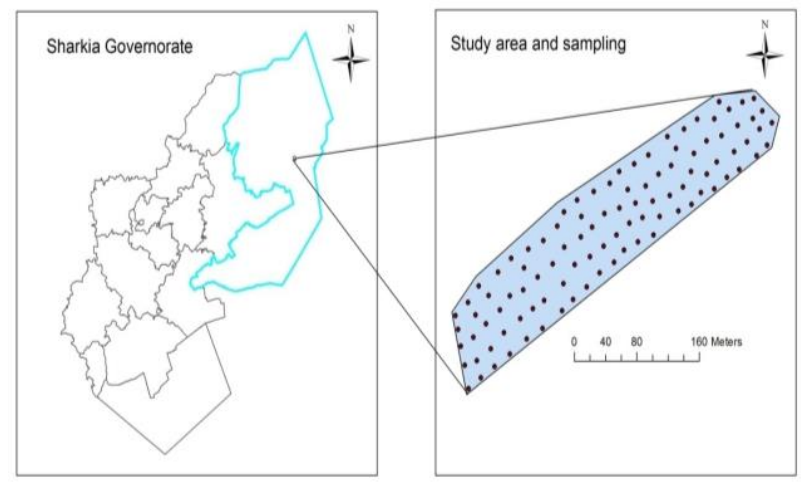

Figure 1. Location of the study area and sampling

Laboratory work

Soil samples were dried, ground and sieved with a $2 \mathrm{~mm}$ sieve and subjected to the following analysis: $\mathrm{pH}$ 
was measured using a glass electrode in 1:2.5 soil water suspension, soil texture fractions (sand, silt and clay) were determined according to the international pipette method (Piper, 1950). Cadmium, zinc and copper contents were extracted by shaking a 1:5 ratio of air-dried soil to $1 \mathrm{M}$ nitric acid solution for two hours according to Mielke et al. (1983). The extracts were filtered, and the final extractions were analyzed using atomic absorption spectrometer (AA analyst Perkin Elmer Instruments), (Shelton, Connecticut, USA).

The soil texture down to $0.20 \mathrm{~m}$ includes two textures of light clay and heavy clay according to the Moeys (2016) as shown in table 1 for 30 soil samples distributed over the field.

Table1. Soil texture classes over the field

\begin{tabular}{lcccc}
\hline Soil Texture class & Number of samples & Sand $(\mathbf{2 0 0}-\mathbf{2 0} \boldsymbol{\mu} \mathbf{m})$ range $(\boldsymbol{\%})$ & Silt $(\mathbf{2 0}-\mathbf{2} \boldsymbol{\mu m})$ range $(\boldsymbol{\%})$ & Clay $(<\mathbf{2} \boldsymbol{\mu m})$ range $(\boldsymbol{\%})$ \\
\hline Heavy clay & 14 & $42.76-21.12$ & $24.82-7.09$ & $59.72-45.29$ \\
Light clay & 16 & $54.34-45.74$ & $13.63-6.03$ & $44.90-39.06$ \\
\hline
\end{tabular}

\section{Geostatistical analysis}

The spatial map of cadmium was developed using ordinary kriging and was classified into three geometric intervals named as (zone 1, zone 2, zone 3). Before map interpolation, an exploratory data analysis was performed to verify the normality of the studied soil variable by calculating the skewness.

\section{Prediction assessment}

Prediction performance was assessed using cross validation (Isaaks and Srivastava, 1989), whereby one observation ( $\mathrm{z}$ ) at a time is temporally detached from the data set and re-estimated $\left(\mathrm{z}^{*}\right)$ from the remaining data. Two statistics were calculated to assess the precision and accuracy of estimation. These are: mean error (ME), as an indicator of bias, and mean standardized squared error (MSSE) (scaled by the predicted standard deviation of estimation), as a measure of accuracy:

$$
\begin{aligned}
\mathrm{ME} & =\frac{1}{\mathrm{~N}} \sum_{\mathrm{i}=1}^{\mathrm{N}}\left(\mathrm{z}_{\mathrm{i}}-\mathrm{z}^{*}\right) \\
\mathrm{MSSE} & =\frac{1}{\mathrm{~N}} \sum_{\mathrm{i}=1}^{\mathrm{N}}\left(\frac{\mathrm{z}_{\mathrm{i}}-\mathrm{z}^{*}}{\sigma}\right)^{2}
\end{aligned}
$$

Where $\mathbf{N}$ is the number of active observations and $\sigma$ the kriging standard deviation.

The first statistic should be close to zero indicating that the estimation is unbiased,whereas the second one should be close to one indicating that the estimation is accurate because it corresponds to the ratio between an experimental variance and a theoretical one (Carroll and Cressie 1996).

\section{Delineation of risky zones}

Delineation of risky zone was performed based on the threshold limit values provided by New York State Department of Environmental Conservation (NYS DEC). NYS DEC are defined for removing human health risks.The unrestricted use involves agricultural use (Table2).

Table 2. Levels of soil heavy metal content in soil used to guide cleanup and land use decisions (mg.kg ${ }^{-1}$ )

\begin{tabular}{lcc}
\hline \multirow{2}{*}{$\begin{array}{l}\text { Heavy metal } \\
\left.\text { mg.kg }^{-1}\right)\end{array}$} & \multicolumn{2}{c}{ NYS DEC } \\
\cline { 2 - 3 } Cadmium & Unrestricted use & Residential use \\
Nickle & 0.43 & 0.86 \\
Copper & 72 & 140 \\
\hline
\end{tabular}

Area and average value for each zone were calculated using the tools available in ArcGIS software 10.1 (USA).

\section{RESULTS AND DISCUSSION}

\section{Descriptive data analysis}

Cadmium content was selected for geostatistical analysis because it was the only variable out of soil heavy metals that exceeds the threshold limit value. Descriptive statistics of cadmium content and $\mathrm{pH}$ (Table 3) show that the two variables are approximately symmetric since the skewness valuesare -0.344 and -0.377 respectively. Hence, the data set can be used directly for geostatistical analysis without transformation.

Table 3. Descriptive statistics of Soil pH and heavy metals

\begin{tabular}{lccccccc}
\hline Variable Count & Min & Max & Mean & \multicolumn{2}{c}{ STD } & \multicolumn{2}{c}{ Skewness Kurtosis } \\
\hline $\mathrm{pH}$ & 100 & 7.62 & 8.35 & 8.04 & 0.155 & -0.377 & 0.065 \\
$\mathrm{Cd}^{2+}$ & 100 & 0.500 & 2.125 & 1.31 & 0.491 & -0.344 & -1.446 \\
$\mathrm{Ni}^{2+}$ & 100 & 15.5 & 37.25 & 22.65 & 5.060 & 1.382 & 1.024 \\
$\mathrm{Cu}^{2+}$ & 100 & 12.75 & 38.00 & 20.69 & 6.029 & 0.568 & -0.799 \\
\hline
\end{tabular}

For Cd content, a stable variogram model was fitted to the experimental variogram with nugget effect of 0.011 , partial sill of 0.288 and range of $262 \mathrm{~m}$ (Table 4 and Fig. 2).A spherical model was fitted to the experimental variogram of $\mathrm{pH}$ with nugget effect of 0.009 , partial sill of 0.0.013 and range of $59.63 \mathrm{~m}$ (Table 4 and Fig. 3)

\section{Table 4. Variogram model parameters}

\begin{tabular}{lcccc}
\hline Variable & Model & Nugget effect & Partial sill & Range (m) \\
\hline $\mathrm{Cd}$ & Stable & 0.011 & 0.288 & 262 \\
$\mathrm{pH}$ & Spherical & 0.009 & 0.013 & 59.63 \\
\hline
\end{tabular}

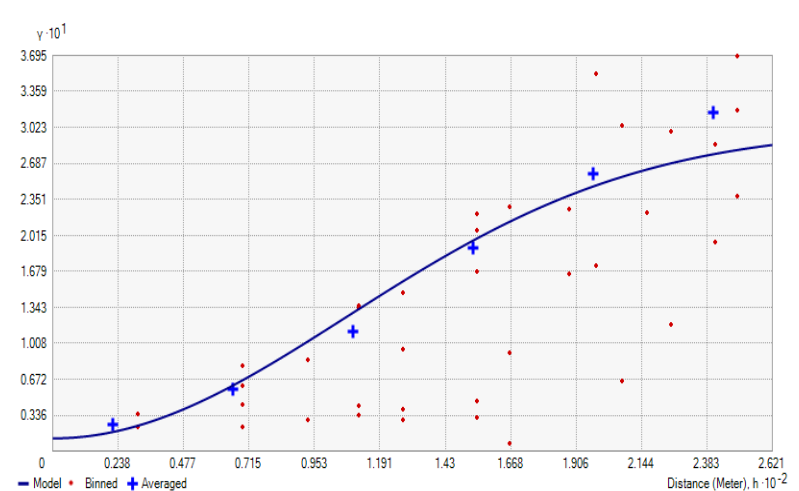

Figure 2. Variogram model for $\mathrm{Cd}$

Table 5 shows the cross-validation results with ME value of -0.004 which is close to zero which indicates that the model is unbiased. The MSSE value is 1.17. Although the MSSE values were somewhat far from 1 but still within the tolerance interval $(0.575-1.425)(1 \pm 3 \sqrt{2} / \mathrm{N}, \mathrm{N}$ is number of observations) (Chiles and Delfiner, 1999), which means that the model is accurate. 


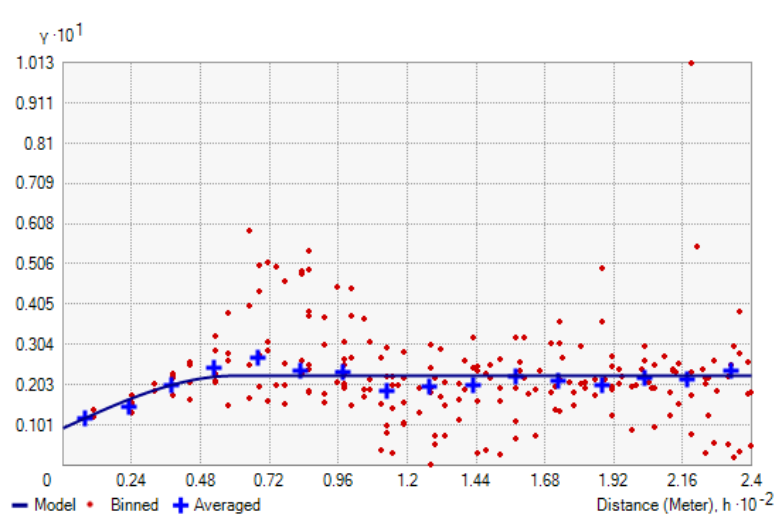

Figure 3. Variogram model for $\mathbf{p H}$

Table 5. Cross-validation results

\begin{tabular}{lcccc}
\hline Variable & Count & ME & MSSE & Tolerance interval \\
\hline $\mathrm{Cd}^{2+}\left(\mathrm{mg} \cdot \mathrm{kg}^{-1}\right)$ & 100 & -0.004 & 1.17 & $0.575-1.425$ \\
$\mathrm{pH}$ & 100 & 0.003 & 0.945 & $0.575-1.425$ \\
\hline
\end{tabular}

Three different zones based on cadmium content were delineated named as zone 1 , zone 2 and zone 3 (table 6). Cadmium content in the three zones indicates that the whole field is considered as a polluted soil for agricultural use.The risk of zone 3 is two times more compared with zone 2 and three times more compared with zone 1 since the threshold limit values for cadmium is $0.43 \mathrm{mg} \cdot \mathrm{kg}^{-1}$. The spatial map of cadmium content (Fig.4) shows that the area with low values of $\mathrm{Cd}$ content (zone 1) was found in the north-eastern part of the field which may be ascribed to the nearness of that area to the water source (drainage water) which indicate a higher infiltration rate $(0.21 \mathrm{~cm} / \mathrm{h})$ compared with zone 2 and zone 3 with infiltration rate of $0.15 \mathrm{~cm} / \mathrm{h}$ and $0.13 \mathrm{~cm} / \mathrm{h}$ respectively. Therefore, the nearer the area to water source the lesser the soil cadmium content even the whole field is considered as polluted soil but with different degrees of Cd pollution. Also, there were two different crops cultivated at the sampling time, berseem (Trifoliumalexandrinum) was grown in the north-eastern partof the study area and wheat (Triticumaestivum) was grown in the rest of the same study area. Berseemwith ahigh biomass crop might be the reason of decreasing soil $\mathrm{Cd}$ content in zonel of the study area as this plant can bioaccumulate soil heavy metals in its tissue more than wheat (Bhatti et al.2016). Precautions should be considered when this plant used for animal as a fodder. It is also important to mention that the area cultivated with wheat being subjected to phosphate fertilizers as a predose -during plowing stage - which contain elevated levels of cadmium and this might be the reason of the high content of cadmium in zones 2 and 3.The fact that the study area being irrigated for about ten years by the drainage water is a great hazard that should be taken into consideration. This means that using the drainage water for irrigation over time would accumulate more cadmium in soil and plants and then the problem will be highly complicated on the long run.

Table 6. Delineation of risky zones

\begin{tabular}{lccc}
\hline Variable & Zone 1 & Zone 2 & Zone 3 \\
\hline Cd range $\left(\mathrm{mg} \cdot \mathrm{kg}^{-1}\right)$ & $0.500-1.140$ & $1.141-1.676$ & $1.677-2.125$ \\
\hline
\end{tabular}

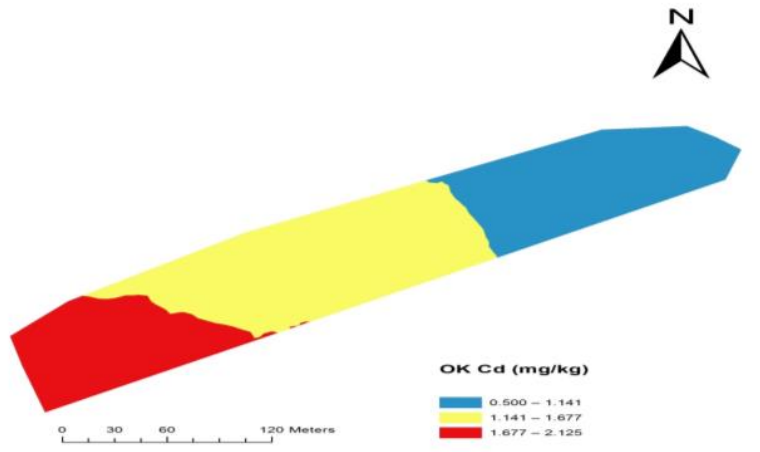

Figure 4. Kriged spatial map of cadmium

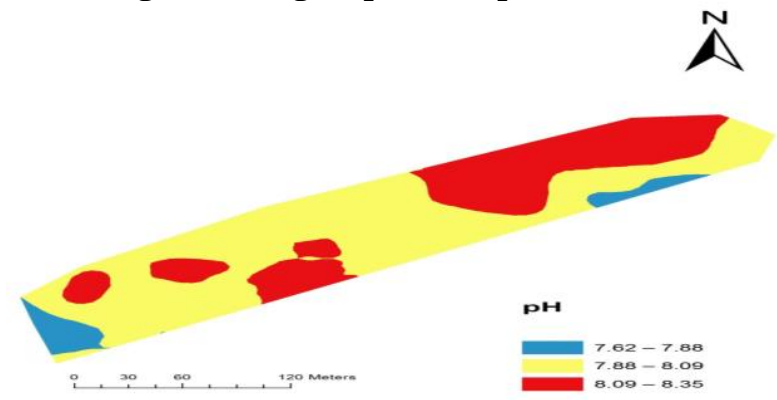

Figure 5. Kriged spatial map of pH

\section{CONCLUSION}

Bahr El-Baqar drain is the main source of irrigation water for soils located at the end of irrigation canals of the neighboring areas where fresh water is insufficient for irrigation. This drain contains various heavy metal pollutants which affect greatly the soil health due to the accumulation of heavy metals in soil. In this work, the spatial variability of cadmium content was investigated as well as the delineation of risky zones based on a threshold limit value. The results showed that the studied area should not be used for agricultural purposes as this negatively affects human and animals' health. However, one would suggest to remediate such soils by planting certain species of plants that could absorb soil pollutants and then used for agriculture when irrigated with another source of irrigation water.

Irrigation water quality assessment systems should be reviewed in relation to the quality of agriculture, and the conditions and type of soil in each area so that all available water sources can be exploited to the fullest extent.

The toxicity concentrations of each heavy metal in irrigation water should be based on the water use period in irrigation, where the permitted concentrations are greater in the case of short-term use compared to the long-term permissible limits.

Appropriate remediation methods for this water before use in irrigation should be applied. Growers should keep continuous monitoring for concentrations of heavy metals, whether in water, soil or plant.

\section{REFERENCES}

Bhatti, S. S., Sambyal, V., \& Nagpal, A. K. (2016). Heavy metals bioaccumulation in berseem (Trifoliumal exandrinum) cultivated in areas under intensive agriculture, Punjab, India. Springer Plus, 5, 173. 
Carroll, S. S., Cressie, N. (1996). A comparison of geostatistical methodologies used to estimate snow water equivalent. Journal of the American Water Resources Association, 32(2), 267-278.

Castrignanò, A. (2011). Introduction to spatial data analysis. Aracne, Rome. ISBN 978-88-548-3978-6.

Chilès JP, Delfiner P (1999). Geostatistics: Modelling Spatial Uncertainty. Wiley, New York. 695 pp.

El-Eweddy, E. A. I., (2000). Factors Affecting the Accumulation Rate of Pollutants in Desert Soils under the Condition of Irrigation with El-Salam Canal Waters, Ph.D. Thesis, Agricultural Sciences, Minufiya University.

Lopez-Granados, F., Jurado-Exposito, M., Pena-Barragan, J. M., Garcia-Torres L (2015) Using geostatistical and remote sensing approaches for mapping soil properties. Eur. J. Agron. 23, 279 - 289.

Meul M, Van Meirvenne M (2003). Kriging soil texture under different types of nonsationarity. Geoderma $112,217-233$.

Mielke, H. W., Anderson, J. C., Berry, K. J., Mielke, P. W., \& Chaney, R. L. (1983). Lead concentrations in inner citysoils as a factor in the child lead problem. AmericanJournal of Public Health, 73, 1366-1369.

Moeys, J. (2016). The soil texture wizard: R-functions for plotting, classifying transforming and exploring soil texture data. Swedish Univ. of Agriculture Sci., Uppsala, Sweden.

Omran, E.E. and Abd El Razek, A. A. (2012). Mapping and screening risk assessment of heavy metals concentrations in soils of the Bahr El-Baker Region, Egypt. Journal of Soil Science and Environmental Management Vol. 6(7), pp. 182195, Available online at http://www. Academic journals.org/JSSEM,ISSN 2141-2391
Onweremadu, E. U., Duruigbo, C. I. (2007). Assessment of $\mathrm{Cd}$ concentration of crude oil pollution arable soils. Int. J. Environ. Sci. Technol. 4:409-412

Park, J. H. and Shin, W. S. (2006). Immobilization of Pb contaminated soil using Modified clay. Water Practice Technol. 1:1-10.

Piper, C.S. (1950). Soil and Plant Analysis. Inter science publ. Inc. New York

Robertsa, T.L., (2014). Cadmium and phosphorous fertilizers: The issues and the science, in: Procedia Engineering. Elsevier, pp. 52-59. https://doi.org/ 10.1016/j.proeng.2014.09.012

Shaddad, S. M., Hendawi, M. Y. (2018). Site-Specific Leaching Map of a Salt Affected Soil in Egypt. Biomed J Sci \&Tech Res 2(4)- BJSTR.MS. ID. 000791. DOI: 10.26717/BJSTR. 2018.02.000791

Shaddad, S.M., Madrau, S., Castrignanò, A., Mouazen, A.M. (2016). Data fusion techniques for delineation of site-specific management zones in a field in UK. Precision Agric. 17 (2), 200-217.

Sumfleth, K., Duttmann, R. (2008). Prediction of soil property distribution in paddy soil landscapes using terrain data and satellite information as indicators. Ecol. Indic. 8,, 485 -501.

Taha A. A., El-Mahmoudi, A. S., El-Haddad, I. M. (2004). Pollution sources and related environmental impacts in the new communitiessoutheast Nile delta, Egypt. Emirates J. Eng. Res. 9(1):35-49.

Yobouet, Y. A., Adouby, K., Trokourey, A., Yao, B. (2010). Cadmium, Copper, Lead and Zinc speciation in contaminated soils. Int. J. Eng. Sci. Technol. 2:802-812.

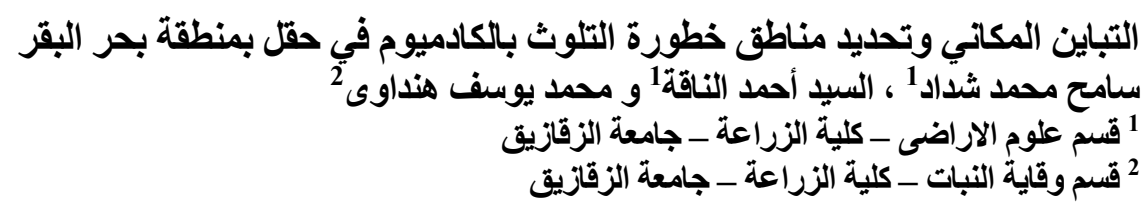

يعتبر تلوث التربة بالعناصر التقبلة من المشكلات الكبرى حيث يؤثر ذلك على جودة النباتات وبالتالي يؤثر على صحة الحيو ان وانئ الانسان.

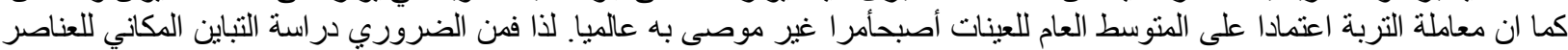

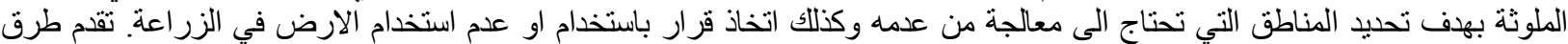

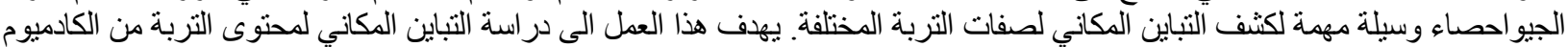

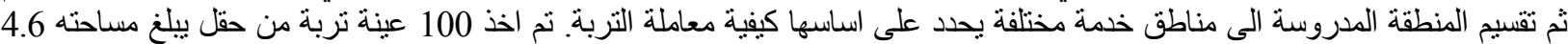
هكتار يقع في منطقة بحر البقر بمحافظة الثرقية وتم تقدير محتوى التربة من التهابة الكادميوم. تم انتاج خرائط التباين المكاني للكادميوم باستخدام

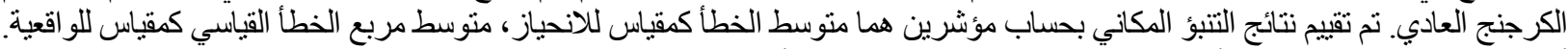

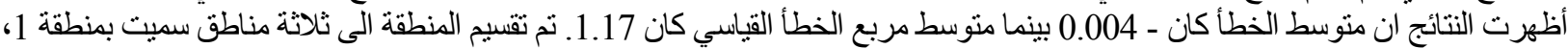

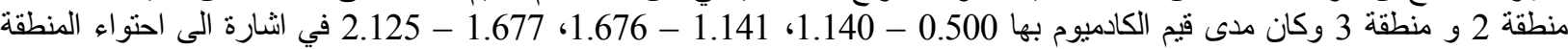

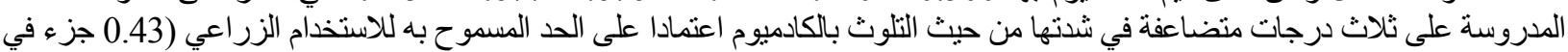

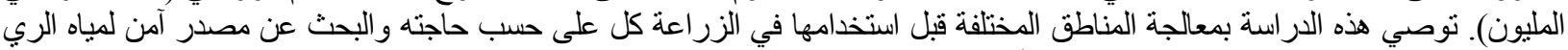

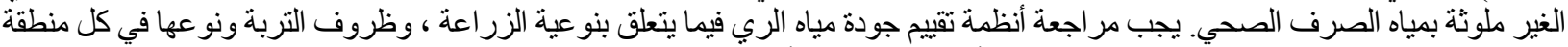

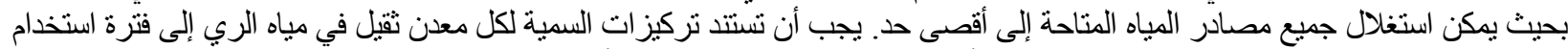

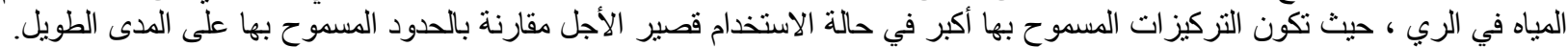

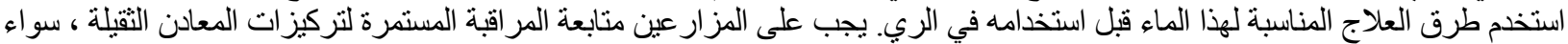
في الماء أو التربة أو النبات. 